IP Periodica Polytechnica Architecture

48(1), pp. 72-78, 2017

https://doi.org/10.3311/PPar.11310

Creative Commons Attribution (i)

RESEARCH ARTICLE

\section{Drawing and Drafting in Architecture Architectural History as a Part of Future Studies}

\author{
Martin Pilsitz $^{1 *}$
}

Received 10 July 2017; accepted 26 July 2017

\begin{abstract}
Architectural historians take an academic interest in past architectural styles and techniques. The actual value of the exploration of the past is to design, from the knowledge gained, a possible image of the future. Consequently, architectural history becomes a part of the futurology. In this context, the first questions are in regard to the fundamental skills of architects. How does work drafting in the architecture? What future presentation methods could be applied? The following article takes a critical look at factors that may influence solutions in the field of drafting in the future, such as the inclusion of the public in the dialogue of the drafting process. This could lead to a discussion about the current didactic for the teaching of drafting and architectural history at universities. Architectural history currently creates a rigid corset for the concepts of styles and for different time frameworks. Is this approach still up-to-date at all? Because of the current teaching method, the vocabulary predominantly originates from the history of art. Accordingly, large numbers of lexical facts are taught and requested, but are there other options available? Against the background of current developments, the question arises: whether architects and architectural historians should not become emancipated and develop, for subject-related issues, their own linguistic forms of expression? If this approach were to be taken into consideration, the knowledge gained and the practical benefits from these studies would be a multiple for the everyday work of prospective architects. As a result, the future of architecture would obtain its own past.
\end{abstract}

\section{Keywords}

Alberti, architecture drawing, drafting, Frigyes Feszl, OTKA, Piranesi, plan archive

\footnotetext{
${ }^{1}$ Department of History of Architecture and of Monuments,

Faculty of Architecture,

Budapest University of Technology and Economics,

1111 Budapest, Müegyetem rkp. 3, Hungary

*Corresponding author, e-mail: Pilsitz.martin@gmail.com
}

\section{Drafting means thinking}

Architecture is undoubtedly considered as a drafting discipline. The situation appears more complicated when it comes to the question of the drafting process. The working methods and approaches differ individually, and their mechanisms can often not, even by the designer, be clearly explained (Krauthausen-Nasim, 2010). Until students gain their degree, they try to develop an own drafting strategy. At first, this might happen through the imitation of legendary models, which often means that magazines with architectural illustrations on glossy paper are searched to find solutions for the drafting task. In a more advanced stage, experiments are carried out with more methodological approaches: graphic-illustrative or morphologic, associative or diagrammatic, inductive or deductive. In the best-case, experiments are carried out with incremental development processes, to break down the process into individual phases and systemise them. Young architects, at the start of their career, assigned to an architecture firm with their first draft plans finally conclude that a large proportion of the drafting process somehow evades objective and factual explanation; for example, the question of the origin of the form in the architecture. Finally, there remains the crucial question: How does drafting work? In the following, this paper will consider various aspects and viewpoints related to these topics, and provide an overview of the complex process of drafting, which has changed depending on cultural context and available tools during history (Gethmann-Hauser, 2009). This raises the crucial issue of how the drafting process will develop in the future. In the overall process, however, other factors, which are not directly associated with the drafting itself, also play a significant role such as the communication of the architect with the public. In addition, the relationships between the drafting process and ethical issues are being dealt with.

Drafting is a difficult to grasp and complex process, whose mechanisms are closely linked to the individual working methods of the architect and can be influenced by their intellectual and physical abilities (ARCH+ 189, 2008). The visualisation methods used to date were quickly established from the early history of drafting: Sketches, drawings, perspectives 
and models, linguistic descriptions and calculations. With the introduction of computer supported drawing in the recent past, a selection of prior defined elements offered by the drawing programme has been added. Also, two further factors contribute to the drafting process: Firstly, methods and strategies to help apply visualisation, and models and examples conditioning the drafter. The summarising function of these individual elements is to make personal concepts and imagination perceptible for the designer themselves and for others. The term drafting becomes in that way a summary definition of a process of various interlocking considerations and handicraft activities, which elude a direct and simple explanation. At the beginning is the focus on the perception of the given situation, which will be followed by the first spectral ideas of the building to be designed, and finally accumulates in the implementation of the building (Ganshirt, 2009). Describing the intellectual processing of the task - the capacity of the mind to imagine - is probably the biggest challenge. Influenced by models (what was seen, read and heard), which are stored in the memory and by external demands to be observed, the process starts both at a conscious and unconscious level. Emotions are an essential element, involved in the same way as imagination, mental attitude and rationality. The processing of information follows rather logical and verbal patterns, while the creation of ideas occurs in pictures in a more intuitive and associative way (Robertson, 2001). The architectural drafting becomes an individual and subjective process of artistic creation. This process does not follow a linear course but represents an interaction between drawing and inspiration. Consequently, it represents drawing and at the same time the tool and the expression of thinking. Due to the permanent flooding of visual stimuli and the constant use of computers, architects currently face challenges to set boundaries, as well as to integrate new tools into the overall process. The related risks and opportunities should be critically reviewed and constantly re-evaluated. Only in this way can responsible development and a conscious use of the new drawing tools, without the immediate need for a new shift of paradigm be ensured. The interaction of the individual factors is so complex that, for example, at the RWTH University Aachen are tools and procedures used in drafting the object of systematic research. In the focus of the attention stands the question as to what extent the drafting process can be made better by the development of own methods, which would serve the integrative processing of heterogeneous and simultaneous information and support the complex management (Staphorst, 2017).

The professional learned and experienced application of the drafting-related mechanisms (abstraction, reduction, change of materials and priorities), allow a variety of experiments, but can also be misused for manipulation. This is favoured by the fact that architecture drafts are always created in some different medium and dimension as the designed object itself. Specifically, in the subscribed and miniaturised abstraction of two-dimensional plans, sections and perspectives, which can only simulate the effect of space, mass, light and material and the body feeling metaphorically in the architectural perception (John, 2009). At the same time, this form of communication of architecture demands the ability of the public to be able to imagine a two-dimensional presentation as a three-dimensional walk-in structure. As many people are not able to fully understand a complex presentation in its spatial consequence, this also brings the possibility of manipulation to the plan. If this connection is thought through to the end, however, the question arises: Could, from these manipulations perhaps develop a new architecture (Cabinet Smith, 2006)? In transitional periods, this statement could be especially applicable. The term "transition" may thereby also relate to a single event, such as the replacement of manual drawing by CAAD-tools towards the end of the 20th century. Alternatively, it may relate to a longer time interval, as the 19th century, with the transformation of the agricultural society to an industrial society and the drastic economic, social and technological changes.

\section{Architecture drawing - drawing of architecture}

One of the traditional means of expression of the draft is the drawing, whose primary task is the visualisation of an idea. The drawing is used at the same time as a means of conviction, to inspire owners and potential investors. The design of the draft is broadly dependent on the cultural trends and technical possibilities of the respective eras. At the same time, the presentation also allows conclusions about the actual drafting process as a creative intellectual performance of the architect, whose goal is to reduce complex issues - as they exist in the built reality - to a few comprehensive aspects. The ability for reduction, which means in this context concentrating on the essential aspects, belongs to the basic knowledge of the architect, and without the drafting process, would not be possible. These interrelations should be clarified and illustrated utilising historical contexts.

The drawing was always a determining means of architectural design. Among the earliest examples of architectural representation, the Gudea statue (Louvre) holding an architectural plan is evidence that drawing already had different contexts in Mesopotamia, some 4000 years ago. The architectural drawing carved into a plate, that is laid on Gudea's knees, represent the orthogonal projection of a temple or sacral building around a shrine, but nevertheless, it had its symbolic meaning besides its technical completeness.

Vitruvius - whose De Architectura Libri Decem is the only surviving comprehensive work of the architectural theories of Classical Antiquity - defines drawing as the means of representing the design. To achieve this, the architect must own clear knowledge of geometry. By defining the notion of ordinatio (fitness), he also defines the ground plan, elevation and perspective to achieve a proper arrangement of the whole building and its parts, all resulting from a rational thinking and invention. 
Leon Battista Alberti (1404-1472), reinvented Vitruvius for the renaissance and introduced to design, with its drawing parts, the equivalence between the original architectural idea and its realisation. The design - defined by Alberti as the primary means of capturing architectural thought, is essentially a critical source from the age of the Renaissance. Alberti's De Re Aedificatoria Libri $X$ is the first summarising theory involving the aspects of societal, scientific and artistic issues of architecture in a complex method.

The rediscovery and systematic processing of the legacy of Classical Antiquity became, from the age of Renaissance, one of the main sources of architectural design. This process is often the main source of architectural creation from the Quattrocento, and, in a slightly biased approach, one can characterise the period spanning from the Renaissance to our time as Memorismus (Hajnóczi, 1993).

One of the highlights of this memory-determined period is the age of Baroque, when archaeological approaches to Antiquity, through scientifically exact depictions, interfere with the needs of new visual attraction and metaphoric content. A master of this complexity of new visual trends is Giovanni Battista Piranesi (1720-1778), an artist whose first field of interest was architecture, although he was expert in various fields of arts and techniques of drawing and etching. His intention to rebuild Rome in its ancient splendour lead him to use the surveyed ruins with visual imagination in a rhetorical way to express his visions. Apart from the unrealistic content of his drawings and etchings, they explore a revolutionary approach in the new use of the classical rules (symmetry, extraordinary scale), which also needed a special drawing technique: a variety of dotted and dashed lines were used that connected different content or figures without giving a definite content with a coherent scale. In this way, his drawings go beyond the mediation of information, following the rules of artistic expression of its own aesthetics.

The 19th century was, for architects, a deep rupture. They were challenged by the introduction of new building materials and related methods of construction. Of particular importance for the construction industry was the breakthrough with Portland cement (1824), profiled steel (1849) and flat glass (1866). These materials revealed new design opportunities, which were unknown previously; they also led to increased demands on construction know-how and higher requirements regarding the understanding of the designer. Until the middle of the 19th Century, traditional building construction (i.e. technical solutions in combination with local experience and a small number of different building materials) had been the norm. However, this underwent a fundamental change from 1850 towards a kind of universal building construction (use of mass products as construction materials, standardisation and prefabrication of components and construction methods that were no longer specific to a particular location) (Pilsitz, 2013). These changes had far-reaching consequences for the position of architects in the 19th century. With the ever-increasing complexity of the construction techniques and the increasing demands on expertise, architects became a new type of trustee of the construction process and thus to the sole professional authority in the area of construction. A new category was formed within the architectural profession in this context: the private architect, self-employed in their own offices, offering services free of attachment to secular sovereigns at own risk. This development represents a far-reaching innovation in the history of the architectural profession. This group of architects was dependent to a previously unknown degree on proving their competence because their order situation was highly dependent on this know-how. An increased performance was also essential, which, in turn, led to the formation of the first associated architect's office communities. These worked based on a division of labour and resulted in the emergence of architects as managing directors of a commercial operating company (Amt, 2010). The associated architect's office of Frigyes Feszl (artistic director), Lipót Kauser (construction supervision) and Károly Gerster (engineering) is a typical example of this new form of work based on a division of labour of a new generation of architects in Budapest in the middle of the 19th century. In the framework of this division of labour, Frigyes Feszl could focus entirely on the artistic, architectural aspects of the profession and could fully unfold his skills in the presentation techniques: painting and drawing (Komárik, 1993).

The first organised archives for architectural drawings and illustrations, in architectural offices and universities, came into existence in this period. The need for systematically collecting the drawings resulted from the preference of securing the drawing but not least also the building idea itself. The constructed buildings are changed over time, suffer damage or are rebuilt, while drawings remain the same in the original form. The plan serves as a medium that contains the original design idea and the construction design, preserving how the building was originally designed and constructed. Whenever something had to be converted, upgraded or repaired, for the future of the building, it is of huge advantage, if the actual planner can visualise the original building idea. This has become even more important, especially as buildings have become increasingly more complicated, and the construction more sophisticated. Similarly, ecclesiastical building authorities or large companies have created plan archives not for reasons of nostalgia, but as an instrument of building maintenance. Architectural drawings not only have a practical or cultural-historical value but also often a high intrinsic artistic value, which represents by no means a subordinate role in the history of the graphic arts, even in the history of the painting. The invention of the perspective, for example, represents an essential means of modern picture presentation (Nerdinger, 1986). Adding to this is still a didactic interest for the universities, which are not focusing alone on drawings, but on all possible testimonies of the design and construction process as well as of finished buildings. In this way, they are, in 
addition to archives, museums and libraries universities, the most important public collectors of architectural drawings. An immediate consequence of the systematisation and professionalisation of architectural education beginning in the middle of the 18th century, was that teaching collections came into existence. These included plaster casts of components and ornaments, models, stitch works, books and prints (later also photographs), and of course, hand drawings from the legacies of architects and other origins (Nägelke, 2012).

The research project entitled "Architectural Drawing and Education" of the Department of History of Architecture and Monument Preservation of the Budapest University of Technology and Economics, focuses on the exploration, archiving and scientific processing of historical architectural drawings collected in the department (and by its predecessors) since the establishment of architectural education at BUTE.

The main aspects and questions of research focus on the general methodological issues of architectural education on a historical basis. One field of this important theme is monument survey, which has always played an important role in the education of architects. The department has played a significant role as a "research base" for Hungarian architecture history writing: on the one hand through its professors' activities as researchers and monument restorers and by the systematic monument surveys completed with student participation on the other. The departments teaching history of architecture - established after 1870 - at that time, were real "laboratories" of historical architecture as the professors with their excellent knowledge base were also active practitioners of design.

Another significant source for design education were the pattern books, notably, the most comprehensive architectural history corpus ever published, the Handbook of Architecture (Handbuch für Architektur).Issued at the beginning of the 20th century, it contained in one series, the knowledge from historical sources to building science and technology issues, being the "Bible" of historicist architecture. The theoretical principle of this method of education was to use historic architectural heritage for both tasks like a contemporary design and study of the past.

Even though the professors of the Faculty were rather conservative in their architectural taste, the need for new architectural language resulting from the development of new structures and new functional approaches had also changed the educational concepts of the first decades of the 20th century. The educational reform proposed in 1919 - even if not put into force characterised the new directions. Soon after this proposal, the Department of Residential Building Design, led by Iván Kotsis, was established as the first truly modern design department, following the modern architectural education trends in Europe. This specialisation is also reflected in the changing principles of structural education, putting more emphasis on real material characteristics and calculation methods.

\section{The future of Architecture Drawing}

Regarding the future of architecture presentation, the computer has completely replaced hand drawing. Consequently, drawing applications and design programs will, it is assumed, continue to largely determine further developments of the aesthetics of the architectural drawing. However, after research of the latest trends and current streams in international architecture, it can be seen that, paradoxically, the opposite is the case. A renaissance of handmade drawing can currently be observed, although in a new form. Architects, on the search for new forms of expression for the 21st century, take the view that the four dimensions of architecture (three for space and one for time) will no longer be sufficient in future. With the objective of a further dimension in architecture presentation, the pure computer graphic must be overcome, and the acceptance and the field of application for individual artistic expression allowed to increase. Terms such as semiotic bliss, cyborgian geography or urban polemic, part of a constantly growing list, describes many individual tendencies. ${ }^{1}$ Just as individual as the architects themselves, the topics and the means of expression to apply them should also be different. This movement of a new architectural presentation is currently in a state of experiment and will remain so. This experimentation includes a broad range of graphic and craft techniques (collages and models) as well as a wide variety of materials (metal, paper, plastic,). It is not intended as a kind of counter movement to computer graphics, but rather to equally apply drawings and other artistic means of expression or to mix or complement different techniques where appropriate (Spiller, 2013). At the same time, it is a tendency to detect the inclusion of social issues and future research those topics that cannot be viewed independently, but as separate dimensions, which should also have an influence on the design process itself. In the search for new forms of expression, the creation process itself finally becomes a part of the overall result. With the factors mentioned above, there are various forms of knowledge available that result in a certain problem-solving know-how relating to some working methods and ways of communication. In the following, shall exemplary be discussed, how architects and artists work, who apply in practice already working methods, which may influence the future development of presentation in the field of architecture.

The projects of Smout and Laura Allen, founders of the office Smout Allen, show the relationship between drawings as carriers of information of scale, materiality and considerations for topographic details and structure, and conversely, the built model, which in the form of an installation, changes its scale continuously during the implementation of the project (Smout-Allen, 2016). In this mode of working, a classic method of drafting

1 These innovations have their origin primarily in the USA and the UK. In these countries architecture is taught as a subject at general universities. It could be debated whether this is the reason that these countries are more likely to produce multidisciplinary interactions and synergies. 
has been implemented with up-to-date tools. Representing the interim results of the drafting process as a comprehensible part of the overall process is considered by Smout and Allen as a key factor. Using the transparency incurred, the result avoids confronting the public only with the final result of the project. The observer, in this way, gets a much greater opportunity to experience the intermediate steps in an understandable way. This mode of operation of a reflexive drafting work, i.e. the integration and analysis of the drafting process, could be a future approach to improved communication in architecture. With this method, the optimisation of the product (building, landscape) would represent not the exclusive aim of the project, but the process would complementary add to shape their design. The Project "Wet Lands": Architectural Waterscapes and Soft Infrastructures for the Thames Gateway, from 2011, shows this approach in an exemplary way (Smout-Allen, 2013).

The experiments of the British architect Simon Herron with graphic expressive collages, drawings and photos show the wide range of possibilities of drawing and creative expressions. One of his famous sayings highlights his attitude to drawing as a process, i.e. as a development of both as well as the drawing and the person drawing it: "This is paper, you can't hurt it." Drawing represents for Simon Herron a ...personal haptic language of the Inventor... (Herron, 2013). Architecture itself is not a neutral thing that comes into existence isolated from social developments or social contexts. Its work consciously includes the creative process of architectural solutions with the involvement of the public. Social and societal challenges such as future, poverty and exclusion are included in the solution process and re-emerge as an equally artistic and architectural dimension. Architecture turns into that what it should be, particularly a response to current problems of society to discuss in public forums (Herron, 2016).

This approach is not about the re-emergence of hand drawing or any form of rejection of computer drawing. New technologies and techniques, innovative media and materials are (re-) discovered, interpreted and used. Parallel to this, a new enthusiasm and longing to use (our) hands in the presentation can be seen. The interaction of different media, such as the digital image, animation, movie, hand drawing and modelling flow into each other, complement each other as information carriers with completely different characters. This raises the question of the form of the interface and the transitions, which in turn opens a wide field of experimentation. There are no limits or restrictive laws. Hand drawing could be perhaps referred to as a cohesive way of thinking, the digital image as a kind of selection, and all that with the objective to expand the range of the possibilities for individual expression. In this way, the architect could be again what they always were: a visionary. The use of different techniques and materials represents the manifestation of a way of thinking: the interdisciplinary work and research. High-tech, low-tech and biotechnology are included in the same way in the presentations as new perspectives and ways of working, as well as ethical considerations. If we assume that synergies between science and art will further strengthen and the processes of design will increasingly involve the public in future, this approach will lead us in the architectural drawing to multimedia, multi-disciplinary and multi-technology. The first essential aspect to develop new possibilities for modes of expression in architecture is to overcome prejudices and lift the taboos. In the following section, three key and exemplary innovations as signs of future developments should be mentioned.

\section{New Materials}

The traditional and historical method of drawing will be in future complemented by new materials and their combinations. The decisive factor here is the combination of traditional manual work and the integration of new materials. The Brazilian artist, Vik Muniz, designs his creations with the use of a wide range of materials such as sugar, peanut butter, threads and many other materials in daily use (Ollman, 2016). At his exhibition in the Mauritshuis in The Hague (Netherlands) from 9 June 2016 to 4 September 2016 drawings fabricated from chocolate were also exhibited (Muniz, 2016). The selection of such design materials may at first affect a slight irritation for some. For Vik Muniz, they are not merely to understand as a gesture but also as a demand for ethical actions. In his film "Waste Land," he reports about people whose whole life is to browse the waste produced by our consumer society on the world's largest dump, the Jardim Gramacho (Rio de Janeiro/Brazil) for something usable for subsequent recycling. This waste will also include considerable discarded food. From Vik Muniz's point of view, these people do the same as he himself, but under inhumane conditions (Walker, 2016).

The Chinese artist Cai Guo-Qiang also produces his drawings with many different materials. Since the end of the 1980s, Cai Guo-Qiang experimented with burning gunpowder. The suddenly ignited flame serves as a symbol of spontaneity, which refers with its bipolarity to the philosophy of his home country (Guao-Qiang, 2016). On the one hand, fireworks, for many generations, have been a source of joy, and on the other, they represent explosions with a destructive force, which caused huge destruction and much pain and suffering in China during the Cultural Revolution (19661976) and the wars of the twentieth century.

An example of materials and media from the non-artistic area is provided by Tim Swager and his team from the Massachusetts Institute of Technology (MIT). The scientists have developed a nano tube-pin, which creates specific drawings depending on the type of gas used (Mirica et al., 2012). Regarding this innovation, a new ink roller pen is also worth mentioning, using instead of conventional ink a special silver conductive fluid that dries immediately after application on the paper. With this pen, functional electronic circuits can be created in a previously unimagined uncomplicated way. The combination 
of visual presentation with simultaneous data transfer adds another level to the possibilities for expression, ensuring that creativity has almost no limits. (Circuit Scribe, 2016).

These examples of non-standard methods are proof that any theory of a privileged form of architecture drawing, can no longer be up-to-date. Even though, traditional drawing retains its justification but is no longer necessarily the best medium for drawings and illustrations for architectural drafts.

\section{Drawing Technology and Media}

In addition to new materials, particularly innovative technologies and media will influence future development. These new technologies are continually expanding intelligence and the practice of drawings and presentations. The following are just a few examples of these technologies.

The $8 \mathrm{~K}$ pixel hyper-real screen is a screen with a resolution of $7680 \times 4320$ pixels. The resolution of this screen is 16 times higher than those of usual $1060 \mathrm{p}$ screens, that results in virtually pixel-free pictures (Silva, 2017).

Procedures using the wave character of light (possibilities of interference and coherence) to create graphical representations systematically, such as holograms, go far beyond the possibilities of classical photography. These motives create an effect as though these objects would 'hovering' free in space. With lateral movements, the observer can also walk around an object that creates an entirely three-dimensional impression. The possibilities of holography for future applications in the presentation of architecture have yet to be fully investigated (Ackermann-Eichler, (2007).

Drawing robots create increasingly complex drawings and barely differ from hand drawings. The development ranges from the drawing robot AARON from 1973 developed by Harold Cohen, up to the ideo genetic machine of Nova Jiang (2012). The corresponding software is subject to continuous development and goes far beyond the simulation of materials. Possibilities are currently being investigated, on how to incorporate factors such as design and room systems with social, psychological and environmental aspects. This may result in massive data linked to drawings and illustrations that can be interconnected directly with global networks as the "Internet of Things" (IoT).

A further phase of innovation represents the body detection technologies, which can detect the observer automatically and interact with it. (Edwards, 2004).

What kind of future is suggested by these technological developments? Every attempt to find an answer to the question must remain an object of speculation with the danger of drifting off into the art form of science-fiction. A theoretical possibility is pictured in the book The Singularity is Near: When Humans Transcend Biology by the futurist Ray Kurzweil from 2006. The basis of his considerations is that systems such as computers, genetics, nanotechnology, robotics and artificial intelligence will develop and network with each other to a point where they are in the position of being able to use neurological scanning to communicate directly with the human nervous system. Ray Kurzweil describes the possibility that images formed in our imagination could be using nano-mechanical or chemical-biological technologies directly visualised in the real world in the form of drawings or other presentational techniques. The idea of animated, intelligent and interactive images is nothing new and goes back to ancient roots explains Marc Garcia in his article Emerging technologies and drawings - The future of images in architectural design (Garcia, 2013). The acheiropoieton, a term from Byzantine etymology means: Made without using the hands. These images are created supernaturally by the gods. The image of the cloth of Veronica, the Shroud of Turin and the Veil of Manoppello are just a few examples of acheiropoieton. Although one can assume on legitimate grounds that these images ultimately have come into existence as a result of earthly forces, they represent the principle acheiropoieton; after the considerations implemented above, a term that has current relevance for architecture drawings. The development of information technology has reached the point where a coupling of certain aspects of scientific process with digital drafting methodologies seems essential. Although the initial CAAD tools were only of an imitative character to replicate the drawing process on paper, these tools have finally been entirely replaced by programs that also enable working with volumes and components. Given the ever-increasing amounts of information, the current software developments also strive to integrate drafting-based decision-making and solution strategies. Such comprehensive systematic and parameter-oriented requirements ultimately raise questions for software programming about the relationship between science (i.e. objectification) and drafting (Ammon and Froschauer, 2013).

\section{Summary}

The objective of the architecture drawing is to visualise future reality. As a two-dimensional image of architectural objects, it consists of iconic characters with the capability of a high degree of abstraction. These combine and unite themselves in a code with a widely understandable formal language based on a geometrical basis (Philipp, 2008). This has barely changed since antiquity. Architecture drawing, therefore, represents the visualised result of drafting, i.e. the output of creative thinking, influenced by the methods and strategies used for visualisation as well as by models and examples conditioning the drafter. The functioning of drafting has changed continuously from the very beginning; as for the future, it shows a development that appears to go far beyond the application of computer programs with special graphics. The experimenting and combining of different presentation techniques and materials will undoubtedly prevail. However, regarding the process of solution finding, for example, by means of a stronger involvement of the public, the future will certainly bring many important innovations. 


\section{Acknowledgement}

This work was supported by the National Research, Development and Innovation Fund (NKFIA) under Grant Number 112906.

\section{References}

Ammon, S., Froschauer, E. M. (2013). Zur Einleitung: Wissenschaft Entwerfen. Perspektiven einer reflexiven Entwurfsforschung. In: Wissenschaft Entwerfen. Vom forschenden Entwerfen zur Entwurfsforschung der Architektur. Wilhelm Fink Verlag. München, pp. 17-18. (in German)

Amt, S. (2009).Von Vitruv bis zur Moderne - Die Entwicklung des Architektenberufs. In: Entwerfen. Architektenausbildung in Europa von Vitruv bis Mitte des 20. Jahrhunderts. Geschichte - Theorie - Praxis, Herausgegeben von Ralph Johannes. Junius Verlag. Hamburg, pp. 10-44. (in German)

ARCH+189 (2008). Raster, Typus, Pattern, Script, Algorithmus, Ornament: Entwurfsmuster. Aachen.

Circuit Scribe (2016). [Documentary film]. Available from: https://www.circuitscribe.com [Accessed: 9th September 2016]

Edwards, M. (ed.) (2004). Detecting foreign bodies in food. Woodhead Publishing Ltd and CRC Press LLC. Cambridge/England.

Ganshirt, Ch. (2009). Zur Geschichte der Werkzeuge des Entwerfens. In: Entwerfen. Architektenausbildung in Europa von Vitruv bis Mitte des 20. Jahrhunderts. Geschichte - Theorie - Praxis, Herausgegeben von Ralph Johannes. Junius Verla. Hamburg, pp. 163-183. (in German)

Garcia, M. (2013). Emerging Technologies and Drawings: The Futures of Images in Architectural Design. Architectural Design. 83(5), pp. 28-35 https:/doi.org/10.1002/ad.1659

Gerhard, K., Ackermann, Eichler, J. (2007). Holographie. Holography: A practical approach. Wiley-VCH. Berlin. 2007. https:/doi.org/10.1007/978-3-642-87011-8

Gethmann, D., Hauser, S. (ed.) (2009). Kulturtechnik Entwerfen. Praktiken, Konzepte und Medien in Architektur und Design Science. Bielefeld, pp. 341-359.

Guao-Qiang, C. (2016). [Documentary film]. Available from: https://youtu.be/ MrTrKJQnwJs [Accessed: 15th April 2016]

Hajnóczi, Gy. (1993). „Memorizmus”. In: Horler Miklós hetvenedik születésnapjára - Tanulmányok. [Müvészettörténet Mủemlékvédelem IV.] Országos Műemlékvédelmi Hivatal, Budapest, pp. 501-506. (in Hungarian)

Herron, S. (2013). Plug-In, Clip-On, Tune-Up: A Throwaway Architecture with Optional Extras. Architectural Design. 83(5), pp. 94-101. https:/doi.org/10.1002/ad.1640

Herron, S. (2016). Lund Architecture Symposium. Nostalgia for the future. University lecture. Lund (Sweden). 2012. [Online] Available from: https://vimeo.com/54923717 [Accessed: 15th April 2016]

Johannes, R. (2009). Vitruv - Römischer Architekt, Vater der Architekturtheorie und Entwurfslehre. In: Entwerfen. Architektenausbildung in Europa von Vitruv bis Mitte des 20. Jahrhunderts. Geschichte - Theorie - Praxis, Herausgegeben von Ralph Johannes. Junius Verlag. Hamburg, pp. 68-80. (in German)
Komárik D. (1993). Frigyes Feszl (1821-1884). Akadémiai Kiadó, Budapest. (in Hungarian)

Krauthausen, K., Nasim, O. (ed.) (2010). Notieren, Skizzieren, Schreiben und Zeichnen als Verfahren des Entwurfs. (=Wissen im Entwurf 3. (Ed.) Barbara Wittmann - Christoph Hoffmann). Berlin.

Mirica, K. A., Weis, J. G., Schnorr, J. M., Esser, B., Swagger, T. M. (2012). Mechanical drawing of gas sensors on paper. Angewandte Chemie- International Edition. 51(43), pp. 10740-10745. https:/doi.org/10.1002/anie.201206069

Muniz, V. (2016). Works. [Homepage]. Available from: https://www.artsy.net/ artist/vik-muniz [Accessed: 15th February 2016]

Nerdinger, W. (ed.) (1986). Die Architekturzeichnung. Vom barocken Idealplan zur Axonometrie. Prestel Verlag. München. (in German)

Nägelke, H. D. (2012). Architekturzeichnungen sammeln. In: Natascha Meuser (Hg.). Handbuch und Planungshilfe - Architekturzeichnungen. DOM Publishers. Berlin, pp. 41-43. (in German)

Ollman, A. (2016). Vik Muniz. DelMonico Books-Prestel. Munich-London-New York.

Philipp, K. J. (2008). Die Imagination des Realen - Eine kurze Geschichte der Architekturzeichnung. In: Schriften der Bauhaus- Universität Weimar. Nr. 120/121. Weimar, p. 147. URN: urn:nbn:de:gbv:wim2-20080814-13949 (in German)

Pilsitz, M. (2013). Early Functionalism as a design principle of historical factory buildings in Budapest. Épités-Épitészettudomány. 41(3/4), pp. 349-371. https:/doi.org/10.1556/Ep-tud.41.2013.3-4.8

Robertson, I. (2001). Problem solving. Psychology Press Ltd. Hove (GB). pp. $62-85$.

Schrank Smith, K. (2006). Architect's Drawings. Elsevier Ltd. Oxford, p. 1

Silva, R. (2017). 8K-Definition and Explanation of 8K Video Resolution. About com. Retrieved February 12. 2014. [Online]. Available from: https://www.lifewire.com/8k-resolution-beyond-4k-1846844 [Accessed: 6th July 2017]

Smout, M., Allen, L. (2013). Augmented Landscapes and Delicate Machinery. Architectural Design. 83(5), pp. 88-93. https://doi.org/10.1002/ad.1639

Smout, M., Allen, L. (2016). Projects. [Homepage]. Available from: https://www.smoutallen.com [Accessed: 4th October 2016].

Spiller, N. (2013). Architectural Drawing-Grasping for the fifth Dimension. Architectural Design. 83(5), pp. 14-19. https://doi.org/10.1002/ad.1657

Stapenhorst, C. (2017). Werkzeugkulturen. [Online]. Available from: https:// de.linkedin.com/in/carolin-stapenhorst-607833a1. [Accessed: 7th June 2017]

Walker, L. (2016). Waste Land. [Documentary film.] Available from: https:// youtu.be/sNlwh8vT2NU [Accessed: 15th September 2016] 